\title{
Nutrient competition experiments with periphyton from the Baltic Sea
}

\author{
Ulrich Sommer*
}

Institut für Meereskunde, Düsternbrooker Weg 20, D-24105 Kiel, Germany

\begin{abstract}
Nutrient competition experiments were performed with periphytic microalgae from the Kiel Fjord, western Baltic Sea. Diatoms were dominant competitors at high Si:N ratios (under N-limited conditions) and high Si:P ratios (under P-limited conditions). Under low silicate supply, cyanobacteria became dominant at low N:P ratios and chlorophytes at high ones. Changes in light intensity influenced the outcome of competition at the species level but not at the level of higher taxa. The nitrogen source (ammonium or nitrate) had no impact on the outcome of competition.
\end{abstract}

KEY WORDS: Periphyton - Microphytobenthos Competition - Nutrients

\section{INTRODUCTION}

Tilman's (1982) competition theory is one of the best tested theories explaining dominance and replacement of species by biotic interactions between populations. Its most prominent prediction is the resource ratio hypothesis, according to which the ratio of the limiting resources determines the taxonomic outcome of competition. So far it has been most intensively applied to phytoplankton communities, both in culture experiments (Sommer 1983, 1986, 1994a, Kilham 1986, Tilman 1977) and in situ (Riegman 1991, Makulla \& Sommer 1993, Sommer 1993, Sommer et al. 1993). Similar attempts with benthic microalgae have been rare. An exception is the study of Fairchild et al. (1985) during which clay pots filled with nutrient enriched agar had been incubated for several weeks in an oligotrophic lake in Alaska. Here, I report on laboratory experiments with benthic microalgae (including filamentous forms) from the Kiel Fjord, western Baltic Sea. The main purpose of my experiments was to investigate whether the major, gross taxonomic findings of competition research with phytoplankton would also apply to periphyton. The working hypotheses to be tested were:

•E-mail: usommer@ifm.uni-kiel.d400.de
(1) High Si:N or Si:P ratios select for diatoms.

(2) Low N:P ratios at low Si supply select for cyanobacteria.

(3) High N:P ratios at low Si supply select for green algae

Additionally, the influence of the nitrogen source (nitrate vs ammonium) and of light intensity was tested.

The study was not designed to mimic the physical conditions under which competition takes place in situ. Factors such as substratum roughness, exposure to wave action, water current velocity, and presence of grazers certainly influence the outcome of competition and must be considered as this line of research continuues to be developed. However, for the purpose of starting experimental competition research with periphyton it was assumed, similarly as for plankton, that there are robust physiological differences between major taxonomic groups which permit the detection of basic patterns in the taxonomic outcome of nutrient competition even under extremely simplified laboratory conditions

\section{MATERIALS AND METHODS}

Periphyton was obtained from the dock in front of the Institute of Marine Research, Kiel, Germany. It was 
Table 1. Flnal nutnent concentration (enrichment plus original seawater)

\begin{tabular}{|rrrrrr|}
\hline Treatment & Silicate & Phosphate & Nitrate & Ammonium & N:P \\
\hline 1 & 1102.5 & 36.14 & 271.4 & 270.7 & $15: 1$ \\
2 & 1102.5 & 3.74 & 271.4 & 270.7 & $145: 1$ \\
3 & 1102.5 & 36.14 & 1.4 & 54.7 & $1.55: 1$ \\
4 & 1102.5 & 36.14 & 55.4 & 0.7 & $1.55: 1$ \\
5 & 112.5 & 36.14 & 271.4 & 270.7 & $15: 1$ \\
6 & 112.5 & 3.74 & 271.4 & 270.7 & $145: 1$ \\
7 & 112.5 & 36.14 & 1.4 & 54.7 & $1.55: 1$ \\
8 & 112.5 & 36.14 & 55.4 & 0.7 & $1.55: 1$ \\
9 & 2.5 & 36.14 & 271.4 & 270.7 & $15: 1$ \\
10 & 2.5 & 3.74 & 271.4 & 270.7 & $145: 1$ \\
11 & 2.5 & 36.14 & 1.4 & 54.7 & $1.55: 1$ \\
12 & 2.5 & 36.14 & 55.4 & 0.7 & $1.55: 1$ \\
13 & 2.5 & 36.14 & 1.4 & 0.7 & $0.06: 1$ \\
\hline
\end{tabular}
in the medium of the agar-plate experiments. Values in $\mu \mathrm{M}$

ity was $14: 10 \mathrm{~h}$, and the experimental temperature was $18^{\circ} \mathrm{C}$. Each light intensity was combined with each nutrient treatment; each combination was duplicated within both series. This means there were 4 replicates for all treatments with the medium and high light intensities and 2 replicates for all treatments with the low light intensity.

It was necessary to test the extent to which the nutrient supply ratios could be distorted relative to the concentration ratios due to differential release of the different ions from the agar. For that purpose $300 \mathrm{ml}$ agar blocks containing the first 5 media were put into $200 \mathrm{ml}$ sterile filtered seawater without nutrient enrichment. The water was replaced by fresh water at scraped off from hard surfaces just below the water line and suspended in filtered water from the sampling site. Then the algal suspension was sieved through a $250 \mu \mathrm{m}$ screen in order to exclude larger filamentous algae and animals. The filtered suspension was equally divided between the different cultures and subjected to the experimental conditions for 6 to $9 \mathrm{wk}$.

Agar-plate experiments. The agar-plate experiments consisted of ca $4 \mathrm{~mm}$ thick $2 \%$ agar layers covered by a $2 \mathrm{~mm}$ water layer in petri dishes. The agar was prepared in filtered in situ water which was enriched by nutrients as shown in Table 1, plus $f / 2$ medium (Guillard \& Ryther 1962) which contains a mixture of trace elements. Nutrient concentrations were designed to provide one set of cultures with a balanced $N: P$ ratio (15:1 by atoms), one set with $N$ strongly limiting relative to $\mathrm{P}(\mathrm{N}: \mathrm{P}=1.55: 1)$, and one set with $\mathrm{P}$ strongly limiting relative to $\mathrm{N}(\mathrm{N}: \mathrm{P}=145: 1)$. The nitrogen enrichment in the P-limited and in the $\mathrm{N}$ :P-balanced media consisted of equimolar amounts of nitrate and ammonium, while there were 2 media in the $\mathrm{N}$-limited set, one with nitrate and the other with ammonium enrichment. Silicate concentrations were $1102.5,112.5$, and $2.5 \mu \mathrm{M}$, respectively. The experimental design was fully factorial, each N:P ratio combined with each Si concentration. In addition, the thirteenth medium was not $\mathrm{N}$-enriched at all in order to select for nitrogen-fixing cyanobacteria

Light was supplied by fluorescent tubes. To balance the low emission of white tubes (Osram 'Biolux') in the red and blue spectral ranges, I combined them with purple ones (Osram 'Fluora'). The light intensities at the surfaces of the petri dishes were 100, 35, and $5 \mu \mathrm{E} \mathrm{m} \mathrm{m}^{-2} \mathrm{~s}^{-1}$ All 3 light intensities were used for the first series of experiments (begun on 12 April 1995). For the second series (begun on 15 May 1995) the lowest light intensity was omitted. The light:dark periodic- logarithmically increasing intervals $(1,2,4,8,16$ d). At each replacement the nutrient concentrations in the water were measured according to standard oceanographic methods (Strickland \& Parsons 1968). Release rates were calculated by dividing the concentration increase in the water by the interval length.

Two times per week, 5 randomly selected samples of $4 \mathrm{~mm}^{2}$ were taken from the plates, fixed by Lugol's iodine and placed into hot $\left(>80^{\circ} \mathrm{C}\right)$ seawater to dissolve the agar. The mixed sample was treated like a plankton sample and counted under an inverted microscope (Utermöhl 1958). A count of 100 to 200 individuals per species gives a $95 \%$ confindence limit of 14 to $20 \%$ if individuals are randomly distributed within the chamber (Lund et al. 1958). Cell volumes were obtained from linear measurements of at least 20 individuals per species and approximation to the nearest standard geometric figure. The competitive success of a species was expressed by its contribution to total biomass ('relative biomass', $p_{i}=B_{i} / B_{\text {tot }}$ ) at the end of the experiments.

Tissue-culture-plate experiments. The tissue culture plates consisted of transparent polystyrene. Each plate comprised 12 chambers. Each chamber was filled initially with $1 \mathrm{ml}$ of the microalgal suspension mixed with $2 \mathrm{ml}$ of one of the 12 experimental media (Table 2). There were 4 levels of silicate $(2.5,5,20$, $80 \mu \mathrm{M}$ ) combined with $3 \mathrm{~N}$.P ratios (P-limited: 45:1; balanced: 15:1; $\mathrm{N}$-limited. 5:1). Nitrogen was supplied as $\mathrm{NH}_{4} \mathrm{NO}_{3}$. Three parallel plates were started on 16 August 1995. The light:dark periodicity was 14:10 h, and the light intensity was $100 \mu \mathrm{E} \mathrm{m}^{-2} \mathrm{~s}^{-1}$ Once per week $2 \mathrm{ml}$ of the supernatant medium was replaced by fresh medium.

The algal film on the bottom of the chambers was inspected directly under an inverted microscope twice per week. This gave a biased view of the algal commu- 
Table 2. Nutrient concentrations $(\mu M)$ in the media used for the tissue-culture-plate experiments (note that $\mathrm{N}$ was supplied as $\mathrm{NH}_{4} \mathrm{NO}_{3}$, which implies 2 atoms of $\mathrm{N}$ per molecule)

\begin{tabular}{|ccccc|}
\hline Treatment & Silicate & Phosphate & Nitrogen & N.P ratio \\
\hline 1 & 80 & 2 & 15 & $15: 1$ \\
2 & 20 & 2 & 15 & $15: 1$ \\
3 & 5 & 2 & 15 & $15: 1$ \\
4 & 2.5 & 2 & 15 & $15: 1$ \\
5 & 80 & 2 & 45 & $45: 1$ \\
6 & 20 & 2 & 45 & $45: 1$ \\
7 & 5 & 2 & 45 & $45: 1$ \\
8 & 2.5 & 2 & 45 & $45: 1$ \\
9 & 80 & 6 & 15 & $5: 1$ \\
10 & 20 & 6 & 15 & $5: 1$ \\
11 & 5 & 6 & 15 & $5: 1$ \\
12 & 2.5 & 6 & 15 & $5: 1$ \\
\hline
\end{tabular}

nity because filamentous algae and their epiphytes extended vertically into the medium. Therefore, the entire content of the chambers was scraped out by a narrow scoop and treated like a plankton sample at the termination of the experiments.

\section{RESULTS}

\section{Agar-plate experiments}

The release rates $\left(R\right.$, in $\left.\mu \mathrm{M} \mathrm{d}^{-1}\right)$ of nutrients from the agar blocks declined rapidly with time. Their change in time could be fitted to the model $R=a t^{b}$ by regression analysis, where $t$ was defined as the midpoint of the incubation intervals (in $\mathrm{d}$ ). The exponents of the regression ( $b$ ) were around -0.5 (Table 3 ). Differences between the exponents of the individual regressions were insignificant. Therefore, the ratio of nutrient release rates could be calculated from the parameter $(a)$ of the regressions. The ratios of the release rates were similar to the concentration ratios in the medium (Table 4). Therefore, the latter were used for further analysis of data.

Species composition stabilized after 3 to $4 \mathrm{wk}$. A regression analysis of the relative biomass of each species against time showed that the slope was no longer significant. This was taken as an indication that competitive equilibrium had been attained. The species composition at the end of the experiments (Figs. 1 to 3 ) showed good replication. Only in 2 treatments (high light, low Si, N:P balanced; and high light, low Si, Plimited) was there a difference in one of the coexisting species under similar nutrient/light conditions but different starting times of the experiments. However, the species replacing each other (Cladophora pygmaea Reinke and Rhizoclonium riparium Harvey) belonged
Table 3 . Time course of the nutrient release rates $\left(\mu \mathrm{M} \mathrm{d}^{-1}\right)$ fitted to the equation $R=a t^{t}$

\begin{tabular}{|ccccc|}
\hline Medium & Nutrient & $a$ & $b \pm \mathrm{SE}$ & $r^{2}$ \\
\hline 1 & $\mathrm{NO}_{3}$ & 20.1 & $-0.51 \pm 0.04$ & 0.98 \\
1 & $\mathrm{NH}_{4}$ & 20.0 & $-0.51 \pm 0.07$ & 0.94 \\
1 & $\mathrm{Si}$ & 79.0 & $-0.53 \pm 0.08$ & 0.94 \\
1 & $\mathrm{P}$ & 2.70 & $-0.51 \pm 0.08$ & 0.94 \\
2 & $\mathrm{NO}_{3}$ & 21.3 & $-0.52 \pm 0.05$ & 0.97 \\
2 & $\mathrm{NH}_{4}$ & 19.3 & $-0.47 \pm 0.05$ & 0.97 \\
2 & $\mathrm{Si}$ & 73.0 & $-0.49 \pm 0.05$ & 0.97 \\
2 & $\mathrm{P}$ & 0.278 & $-0.49 \pm 0.10$ & 0.89 \\
3 & $\mathrm{NO}_{3}$ & - & - & - \\
3 & $\mathrm{NH}_{4}$ & 3.94 & $-0.48 \pm 0.07$ & 0.94 \\
3 & $\mathrm{Si}$ & 76.7 & $-0.49 \pm 0.08$ & 0.93 \\
3 & $\mathrm{P}$ & 2.62 & $-0.50 \pm 0.07$ & 0.95 \\
4 & $\mathrm{NO}_{3}$ & 4.10 & $-0.47 \pm 0.05$ & 0.97 \\
4 & $\mathrm{NH}_{4}$ & - & - & - \\
4 & $\mathrm{Si}_{4}$ & 76.7 & $-0.48 \pm 0.06$ & 0.96 \\
4 & $\mathrm{P}$ & 2.66 & $-0.50 \pm 0.08$ & 0.93 \\
5 & $\mathrm{NO}_{3}$ & 20.3 & $-0.50 \pm 0.10$ & 0.90 \\
5 & $\mathrm{NH}_{4}$ & 20.1 & $-0.53 \pm 0.07$ & 0.94 \\
5 & $\mathrm{Si}_{5}$ & 8.33 & $-0.49 \pm 0.06$ & 0.95 \\
5 & $\mathrm{P}$ & 2.48 & $-0.46 \pm 0.07$ & 0.94 \\
\hline
\end{tabular}

Table 4: Stoichiometric nutrient ratios calculated from concentrations and from release rates

\begin{tabular}{|ccccc|}
\hline Medium & $\begin{array}{c}\text { Si:N } \\
\text { release }\end{array}$ & $\begin{array}{c}\text { Si:N } \\
\text { conc. }\end{array}$ & $\begin{array}{c}\text { N:P } \\
\text { release }\end{array}$ & $\begin{array}{c}\text { N:P } \\
\text { conc. }\end{array}$ \\
\hline 1 & 1.97 & 2.03 & 14.9 & 15.0 \\
2 & 1.90 & 2.03 & 146 & 145 \\
3 & 19.5 & 19.7 & 1.50 & 1.55 \\
4 & 18.7 & 19.7 & 1.54 & 1.55 \\
5 & 0.206 & 0.208 & 16.4 & 15.0 \\
\hline
\end{tabular}

to the same family (Cladophoraceae). In most other cases, the differences between the $p_{i}$ values of individual species were $<0.2$ between replicates.

Distinctive competitive optima were found for a number of species:

Cyanobacteria: Microcoleus chtonoplastes Thuret, a known nitrogen-fixer (Paerl 1988), was the dominant competitor at high and medium light intensities, low Si levels and low N:P ratios. At low light intensities under these nutrient conditions the cyanobacteria consisted of Lyngbya gracilis Rabenhorst.

Chlorophyta: Cladophora pygmaea or Rhizoclonium riparium was dominant at high light intensities, low Si levels and high N:P ratios. Ulothrix implexa Kütz. dominated at medium light intensities and Capsosiphon fulvescens Setchell \& Gardner at low light intensities.

Phaeophyta: The brown algae were only represented by Ectocarpus siliculosus Lyng. which contributed substantially to algal biomass at medium light intensities, low and medium Si levels and low N:P ratios. 
AGAR, HIGH LIGHT

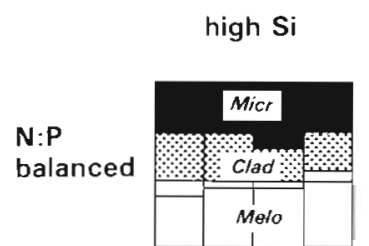

medium $\mathbf{S i}$

low Si
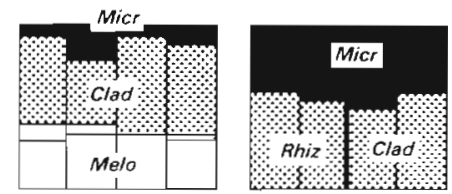

P. limited
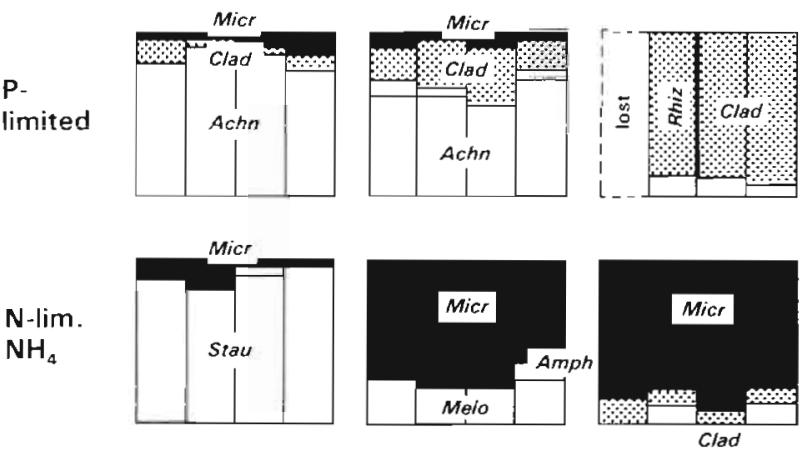

N-lim.
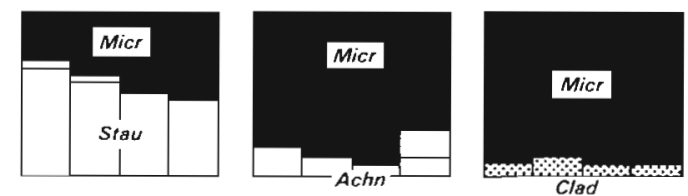

Cyanobacteria

\section{Chlorophyta}

Bacillariophyta

$100 \mu \mathrm{E} \mathrm{m}^{-2} \mathrm{~s}^{-1}$

Fig 1 Final species composition of the periphyton biomass in

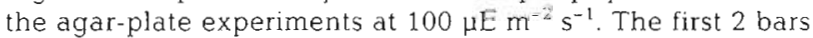
in each block refer to the experiments started on 12 April; the third and fourth bar refer to the experiments started on 15 May. Achn: Achnanthes brevipes; Amph: Amphipleura rutilans; Clad: Cladophora pygmaea; Melo: Melosia nummuloides; Micr-Microcoleus chtonoplastes; Rhiz: Rhizoclonıum riparium; Stau: Stauroneis constricta

Diatoms: Melosira nummuloides Ag. was the only centric species of importance. It had its competitive optimum at medium light intensities, high Si levels and a balanced N:P ratio. Achnanthes brevipes Ag. was dominant at high light intensities, high Si levels and high N:P ratios. Stauroneis constricta Cleve was a dominant species at all light intensities, high Si levels and low N:P ratios. Amphipleura rutilans Cleve was most important at medium light intensities, medium Si levels and high N:P ratios. Synedra (= Fragilaria) tabulata Kütz. also preferred medium light intensities and high $N: P$ ratios, but high $S i$ levels. An unidentified, small $(<8 \mu \mathrm{m}$ length) Navicula sp. had its optimum at low light intensities, medium Si levels and low N:P ratios.
AGAR, MEDIUM LIGHT

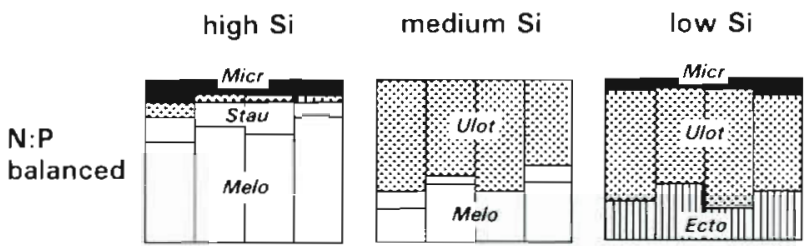

P.

limited
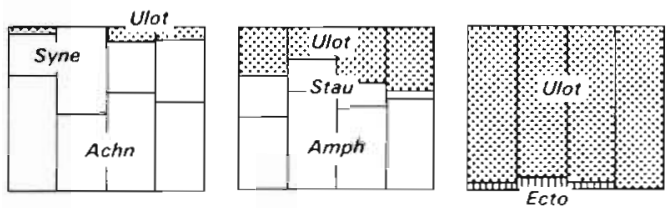

$\mathrm{N}$-lim. $\mathrm{NH}_{4}$
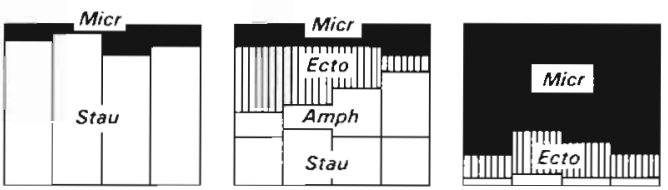

$N-\lim$
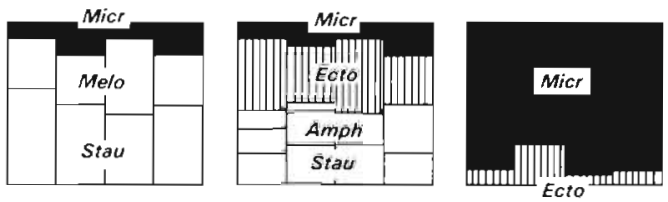

Cyanobacteria

Chlorophyta

Bacillariophyta

no $N$

Phaeophyta

$$
35 \mu \mathrm{E} \mathrm{m}^{-2} \mathrm{~s}^{-1}
$$

Fig 2. Final species composition of the periphyton biomass in

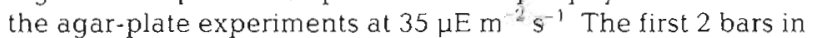
each block refer to the experiments started on 12 Aprili the third and fourth bars refer to the experiments started on 15 May. Achn: Achnanthes brevipes; Amph: Amphipluera rutilans; Ecto: Ectocarpus siliculosus; Melo: Melosira nummuloides; Micr Microcoleus chtonoplastes; Stau: Stauronels constricta; Syne: Synedra tabulata; Ulot: Ulothrix implexa

The working hypotheses stated in the introduction were tested by a multiple regression analysis with stepwise variable selection. The dependent variable was the arcsine square-root transformed relative biomass $\left(\arcsin v p_{1}\right)$ of higher taxa (diatoms, chlorophyta, cyanobacteria). The arcsine square-root transformation was necessary to obtain a normal distribution of the residuals. The independent variables were the $\log _{10}$ transformed values of the light intensity $(I)$ and of the stoichiometric nutrient ratios, $\mathrm{N}: \mathrm{P}, \mathrm{NO}_{3}: \mathrm{NH}_{4}$, and Si:( $N$ or $P$ ) The latter ratio needs some explanation: nutrient ratios are only meaningful predictors if both nutrients are limiting (Tilman 1982). In order to make Si:N and Si:P ratios numerically comparable, the molar 


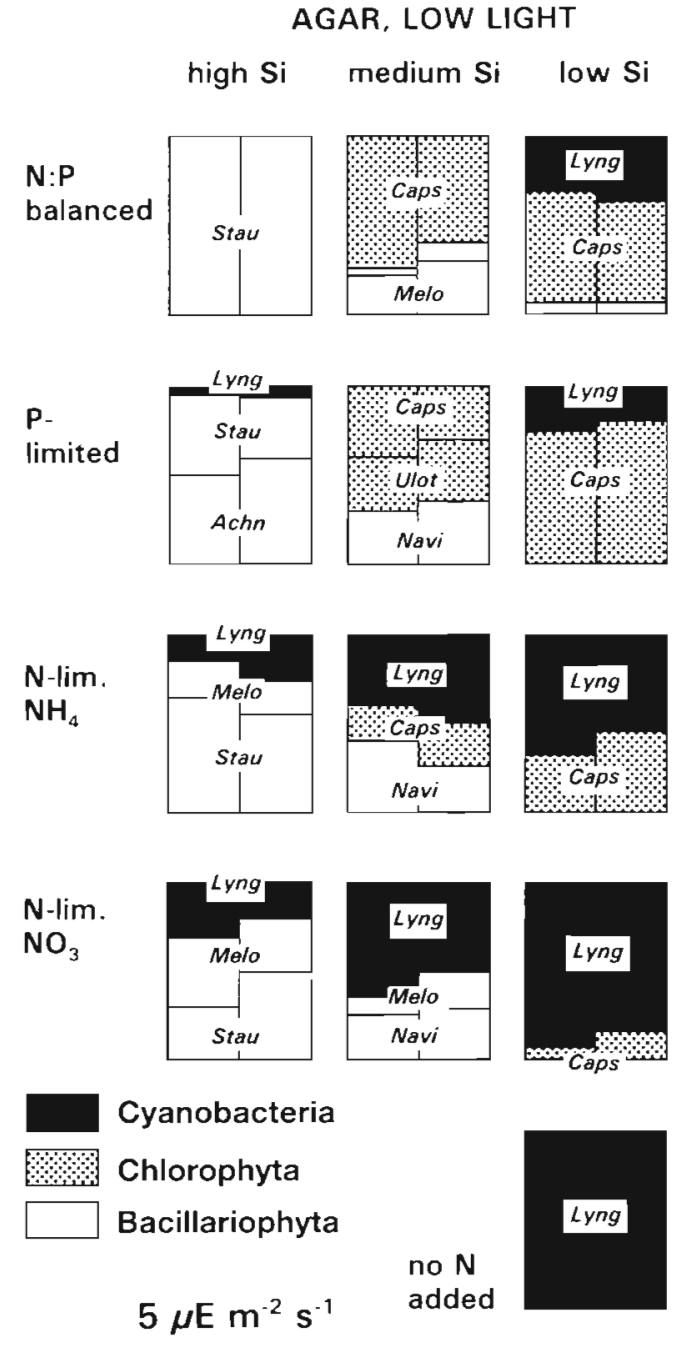

Fig 3. Final species composition of the periphyton biomass in the agar-plate experiments at $5 \mu \mathrm{E} \mathrm{m^{-2 }} \mathrm{s}^{-1}$ Caps: Capsosiphon fulvescens; Lyng: Lynbgbya gracilis; Melo: Melosira nummuloides; Navi: Navicula sp.; Stau: Stauroneis constricta; Ulot: Ulothrix implexa

concentration of $\mathrm{P}$ was replaced by the 15 -fold concentration under P-limiting ( $\mathrm{N}: \mathrm{P}>15)$ conditions and this value was related to the Si concentration. Independent variables were admitted to the final model after a Bonferroni correction of the significance threshold, which means a corrected threshold of $p<0.0125$ instead of $p<0.05$ for 4 tested variables. Variables which failed to yield a significant response were excluded from the final model. The final models did not include light or the $\mathrm{NO}_{3}: \mathrm{NH}_{4}$ ratio and they confirmed the predictions stated in the introduction

$$
\begin{gathered}
\text { Diatoms: } \arcsin \sqrt{ } p_{i}=0.45+0.40 \log _{10} \\
\text { (Si: } N \text { or } P)+0.18 \log _{10}(\mathrm{~N}: \mathrm{P}) \\
r^{2}=0.81 ; \mathrm{p}<0.0001
\end{gathered}
$$

$$
\begin{gathered}
\text { Cyanobacteria: } \arcsin \vee p_{i}=0.89-0.15 \log _{10} \\
\text { (Si:N or P) }-00.40 \log _{10}(\mathrm{~N}: \mathrm{P}) \\
\mathrm{r}^{2}=0.69 ; \mathrm{p}<0.0001 \\
\text { Chlorophyta: } \arcsin \vee p_{1}=0.14-0.21 \log _{10} \\
\text { (Si: } \mathrm{N} \text { or } \mathrm{P})+0.26 \log _{10}(\mathrm{~N}: \mathrm{P}) \\
\mathrm{r}^{2}=0.66 ; \mathrm{p}<0.0001
\end{gathered}
$$

The conclusions are that the proportion of diatoms is positively related to Si:N or Si:P and to N:P ratios. Cyanobacteria are negatively influenced by high $\mathrm{Si}: \mathrm{N}$ or Si:P ratios and by high N:P ratios. Chlorophyta are negatively influenced by high $\mathrm{Si}: \mathrm{P}$ or $\mathrm{Si} \mathrm{N}$ ratios but positively influenced by high N:P ratios.

\section{Tissue-culture plate experiments}

The tissue-culture experiments were conducted for $9 \mathrm{wk}$, although the species composition of the bottom flora had already stabilized after 4 wk. Again, there was a satisfactory replication between parallel treatments. At the level of higher taxa, the same trends showed up as in the agar-plate experiments (Fig. 4). Under $\mathrm{P}$ limitation (N:P $=45: 1$ ) diatoms dominated at high Si:P ratios and were gradually replaced by green algae at declining ratios. Under a balanced supply of $\mathrm{N}$ and $P$ (15:1) diatoms were displaced by green algae and cyanobacteria as Si:P or Si:N ratios declined. Under N-limitation ( $\mathrm{N}: \mathrm{P}=5: 1$ ) diatoms dominated at high Si:N ratios and cyanobacteria at low ones. A multiple regression analysis performed in the same way as for the agar-plate experiments confirmed these trends:

$$
\begin{gathered}
\text { Diatoms: } \arcsin \sqrt{ } p_{1}=0.50+0.69 \log _{10} \\
\text { (Si: } N \text { or } \mathrm{P})+0.25 \log _{10}(\mathrm{~N}: \mathrm{P}) \\
\mathrm{r}^{2}=0.94 ; \mathrm{p}<0.0001 \\
\text { Cyanobacteria: } \arcsin \sqrt{ } p_{i}=1.47-0.34 \log _{10} \\
\text { (Si:N or P) }-0.95 \log _{10}(\mathrm{~N}: \mathrm{P}) \\
\mathrm{r}^{2}=0.91 ; \mathrm{p}<0.0001 \\
\text { Chlorophyta: } \arcsin \sqrt{ } p_{1}=-0.30-0.32 \log _{10} \\
\text { (Si:N or P) }+0.70 \log _{10}(\mathrm{~N}: \mathrm{P}) \\
\mathrm{r}^{2}=0.81 ; \mathrm{p}<0.0001
\end{gathered}
$$

At the species level there were differences to the agarplate experiments:

Calothrix aeruginosa Thuret was the only cyanobacterium under N-limiting and N:P-balanced conditions. This species fixes molecular nitrogen. Microcoleus chtonoplastes formed small populations under P limitation and low Si:P ratios. The green algae were represented only by Rhizoclonium riparium.

Among the diatoms, Amphipleura rutilans Cleve dominated under $\mathrm{P}$ limitation and high Si:P ratios, whereas Entomoneis paludosa Reimer dominated under $\mathrm{N}$ limitation and high Si:N ratios. Under a bal- 


\section{TISSUE PLATES, HIGH LIGHT}

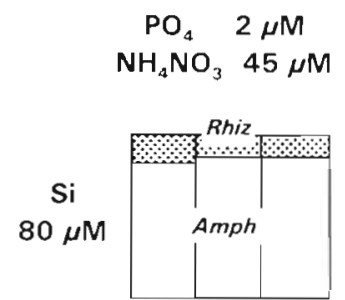

$\mathrm{PO}_{4} 2 \mu \mathrm{M}$
$\mathrm{NH}_{4} \mathrm{NO}_{3} 15 \mu \mathrm{M}$

$\mathrm{PO}_{4} 6 \mu \mathrm{M}$
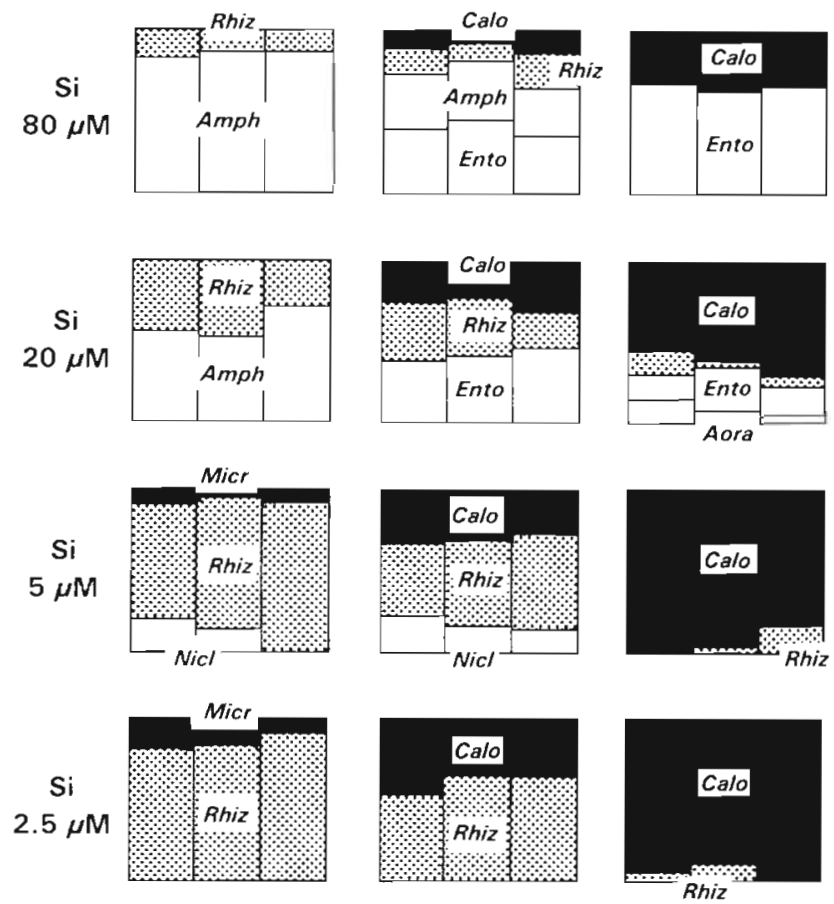

Cyanobacteria

Chlorophyta

Bacillariophyta

Fig. 4. Final species composition of the periphyton in the tissue-culture-plate experiments. Amph: Amphipleura rutilans; Aora: Amphora flebilis; Calo: Calothrix aeruginosa; Ento: Entomoneis paludosa; Nicl: Nitzschia closterium; Micr. Microcoleus chtonoplastes; Rhiz: Rhizoclonium riparium

anced supply both species coexisted at the highest $\mathrm{Si}$ concentration. Nitzschia closterium Smith formed a small population at $5 \mu \mathrm{M}$ Si and P-limited conditions and at $\mathrm{N}: \mathrm{P}=15: 1$

\section{DISCUSSION}

It was not my intention to mimic natural conditions in these experiments. Instead, I intended to discover robust patterns in the competitive response of periphyton communities to various nutrient ratios. This philosophy had been successful in phytoplankton ecology and there was no a priori reason why it should not work in periphyton. Conditions in in vitro competition experiments differ considerably from natural conditions. Some of the differences are an inherent necessity in experimentation because the effects of competition as the mechanism under study have to be isolated from confounding influences such as grazing and physical disturbances. Other differences concern the surface properties of growth substrata, restrictions of 3-dimensional growth, and the impact of water movements which transport both organisms and nutrients.

The potential impact of some of the differences in physical conditions can be seen by comparing the agar-plate and the tissue-culture-plate experiments. Agar is known to be a highly selective medium, thus restricting the number of species from which competitive winners can be selected. In addition to the surface properties of agar, the agar plates enforced a 2-dimensional growth mode with tight contact to the surface of the agar. In the tissue-culture plates, filamentous algae could grow in an erect mode and serve as a substratum for the growth of epiphytic unicells. This difference in the 'architecture' (sensu Wetzel 1983) of the periphyton community probably accounted for much of the difference at the species level between both types of cultures. Despite the species differences there was good agreement in the competitive performance of higher taxa. This agreement even extends to the competitive performance of higher taxa in phytoplankton communities. Therefore, it seems plausible that the physiological requirements and abilities which are decisive for the outcome of nutrient competition show a sufficient degree of uniformity within higher taxa to make comparisons between laboratory experiments and natural sites possible.

The major findings of my experiments were:

Light has a strong impact on the selection of competitively dominant species, but it does not determine at which Si:P or Si:N ratios diatoms become dominant. The same has been found for marine phytoplankton (Sommer 1994b).

The nitrogen source (ammonium vs nitrate) has no important impact on the outcome of nitrogen competition, although in theory changes in the ratio of substitutable resources could be important (Tilman 1982). Similar results have been found for marine (Sommer 1995, 1996) and for freshwater phytoplankton (Makulla 1995)

Under P-limited conditions diatoms become increasingly dominant with increasing Si:P ratios. Under $\mathrm{N}$ limited conditions the same happens with increasing $\mathrm{Si} \mathrm{N}$ ratios. So far, the increase of diatoms with increasing Si:P ratios has been reported from experiments with freshwater phytoplankton (Sommer 1983, Kilham 1986, Tilman et al. 1986) and the increase of diatoms with increasing Si:N ratios from experiments with marine phytoplankton (Sommer 1986, 1994a, 1995. 1996).

Under low Si supply cyanobacteria dominate at low $N: P$ ratios and chlorophytes at high ones. This pattern has been reported for freshwater phytoplankton (Tilman et al. 1986) but not for marine phytoplankton where chlorophytes are usually quite unimportant. 
The dominance of diatoms decreases with decreasing N:P ratios, but this effect is not strong enough to prevent diatom dominance at high Si:N ratios. This pattern has not previously been reported.

\section{LITERATURE CITED}

Fairchild GW, Lowe RL, Richardson WB (1985) Algal periphyton growth on nutrient-diffusing substrates: an in-situ bioassay. Ecology 66:465-472

Guillard RRL, Ryther JH (1962) Studies on marine diatoms. 1. Cyclotella nana Hustedt and Detonula confervacea Gran. Can J Microbiol 8:229-239

Kilham SS (1986). Dynamics of Lake Michigan phytoplankton communities in continuous culture along a Si:P loading gradient. Can J Fish Aquat Sci 43:351-360

Lund JWG, Kipling C, LeCren ED (1958) The inverted microscope method of estimating algal numbers and the statistical basis of estimations by counting. Hydrobiologia 11. $143-170$

Makulla A (1995) Einfluß der Konkurrenz um die Stickstoffverbindungen Nitrat und Ammonium auf die Artenzusammensetzung des Phytoplanktons im Großen Binnensee. $\mathrm{PhD}$ thesis, University of Oldenburg

Makulla A, Sommer U (1993) Relationships between resource ratios and phytoplankton species composition during spring in five North German lakes. Limnol Oceanogr 38: $846-856$

Paerl H (1988) Growth and survival strategies of blue-green algae (cyanobacteria). In: Sandgren CD (ed) Growth and reproductive strategies of freshwater phytoplankton. Cambridge Univ Press, Cambridge, p 261-315

Riegman R (1991) Mechanisms behind eutrophication induced novel algal blooms. NIOZ Rapp 9:1-51

Sommer U (1983) Nutrient competition between phytoplank-

This article was submitted to the editor ton in multispecies chemostat experiments. Arch Hydrobiol 96:399-416

Sommer U (1986) Nitrate- and silicate-competition among Antarctic phytoplankton. Mar Biol 91:345-351

Sommer U (1993) Phytoplankton competition in Plußsee: a field test of the resource ratio hypothesis. Limnol Oceanogr 38:838-845

Sommer U (1994a) Are marine diatoms favoured by high Si:N ratios? Mar Ecol Prog Ser 115:309-315

Sommer U (1994b) The impact of light intensity and daylength on silicate and nitrate competition among marine phytoplankton. Limnol Oceanogr 39:1680-1688

Sommer U (1995) Eutrophication related changes in phytoplankton species composition: is there a role of nutrient competition? 1995 ICES Conference, manuscript T:7. Aalborg

Sommer U (1996) Phytoplankton ecology: the last two decades of progress. Naturwiss 83:293-301

Sommer U, Gaedke U, Schweizer A (1993) The first decade of oligotrophication of lake Constance. 2. The response of phytoplankton taxonomic composition. Oecologia 93: 276-284

Strickland JDH, Parsons TR (1968) A practical handbook of seawater analysis. Bull Fish Res Bd Can 169

Tilman D (1977) Resource competition between planktonic algae: an experimental and theoretical approach. Ecology $58: 338-348$

Tilman D (1982) Resource competition and community structure. Princeton Univ Press, Princeton

Tilman D, Kiesling R, Sterner RW, Kilham SS, Johnson FA (1986) Green, bluegreen and diatom algae: taxonomic differences in competitive ability for phosphorus, silicon, and nitrogen. Arch Hydrobiol 106:473-485

Utermöhl H (1958) Zur Vervollkommnung der quantitativen Phytoplankton-Methodik. Mitt Int Verein Limnol 9:1-38

Wetzel RG (1983) Recommendations for future research on periphyton. in: Wetzel RG (ed) Periphyton of freshwater ecosystems. Junk, The Hague, p 339-346

Manuscript first received: December 22, 1995

Revised version accepted: June 6, 1996 